\title{
PENINGKATAN MOTORIK KASAR ANAK MELALUI PERMAINAN TRADISIONAL PETAK UMPET DI TAMAN KANAK-KANAK
}

\author{
$\operatorname{Ashar}^{1 \otimes}$ \& Inrawulan ${ }^{2}$ \\ ${ }^{12}$ Pendidikan Guru Pendidikan Anak Usia Dini, Universitas Islam Makassar
}

\begin{abstract}
:
This study applies traditional games that can improve gross motor skills of early childhood, in this case the hope is that it uses a fast and appropriate way of traditional games, so this study aims to determine the level of gross motor skills of children through the traditional game hide and seek group B in kindergarten. Az-zahra. The type of research used is classroom action research. held at TK Az-zahra Kec. Biring Romang, Makassar City, with the number of children studied, namely 15 children, 7 boys and 8 girls. Data collection techniques used are observation and documentation. The results obtained after doing the research, the level of gross motor skills of children with the data obtained in the first cycle only reached $84 \%$, while in the second cycle it has reached $97 \%$ with the very well developed category.
\end{abstract}

Keywords: Gross motoric, traditional games

\begin{abstract}
Abstrak:
Penelitian merupakan penerapan permainan tradisional yang dapat meningkatkan kemampuan motorik kasar anak usia dini dalam hal ini harapannya menggunakan cara yang cepat dan tepat pada permainan tradisional tersebut, sehingga penelitian ini bertujuan untuk mengetahui tingkat kemampuan motorik kasar anak melalui permainan tradisional petak umpet kelompok B di TK Az-Zahra. Jenis Penelitian yang digunakan yaitu penelitian tindakan kelas (classroom action research). dilaksanakan di TK Az-zahra Kec. Biring Romang, Kota Makassar, dengan jumlah anak yang diteliti yaitu 15 anak 7 anak laki-laki dan 8 anak perempuan. Teknik pengumpulan data yang digunakan yaitu dengan observasi dan dokumentasi. Hasil penelitian didapatkan setelah melakukan penelitian maka tingkat kemampuan motorik kasar anak dengan data yang diperoleh pada siklus I yaitu hanya mencapai $84 \%$ sedangkan pada siklus II telah mencapai 97\% dengan kategori berkembang sangat baik.
\end{abstract}

Kata Kunci: Motorik kasar, permainan tradisional 


\section{PENDAHULUAN}

Pendidikan anak usia dini merupakan upaya pembinaan dan pengasuhan yang ditujukan kepada anak sejak lahir hingga usia 6 tahun, meskipun sesungguhnya akan lebih optimal lagi apabila ditujukkan kepada anak sejak dalam kandungan hingga usia 8 tahun. Tujuannya adalah membantu mengembangkan seluruh potensi dan kemampuan fisik, intelektual, emosional, moral dan agama secara optimal dalam lingkungan pendidikan yang kondusif, demokratis dan kompetitif. Perkembangan motorik kasar merupakan perkembangan jasmani yang melalui kegiatan pada pusat syaraf, dan otot yang terkoordinasi.Pada saat anak berumur 4-5 tahun anak dapat mengendalikan gerakan secara kasar yang melibatkan bagian badan seperti berjalan, berlari melompat dan lain-lain. Endang (2007) menyatakan bahwa perkembangan motorik adalah perkembangan pengendalian gerak jasmaniah melalui kegiatan pusat saraf, urat saraf, dan otot terkoordinasi.

Anak usia dini adalah anak yang berumur 0 sampai 6 tahun, yang dimana pada usia ini merupakan suatu hal yang sangat penting bagi perkembangan dan pembentukkan sikap, perilaku, dan karakter kepribadian pada anak tersebut, Karena usia 0 sampai 6 tahun adalah usia yang mengalami pertumbuhan dan perkembangan yang sangat pesat atau disebut dengan masa emas (golden age). Pendidikan anak usia dini khususnya di Taman Kanak-Kanak pada dasarnya adalah pendidikan yang diselenggarakan dengan tujuan untuk memfasilitasi pertumbuhan dan perkembangan anak secara menyeluruh atau menekankan pada pengembangan seluruh aspek anak. Pendidikan taman kanak-kanak pada anak usia dini juga dikatakan sebagai masa kreatif yang diyakini bahwa kreativitas yang ditunjukkan anak merupakan bentuk kreativitas yang original dengan frekuensi kemunculannya tanpa terkendali. Untuk itu pendidikan anak usia dini sangat penting untuk menstimulasi pertumbuhan dan perkembangan anak dan mengembangkan kecerdasan anak. Berdasarkan hasil observasi awal TK Az-zahra menunjukkan bahwa kemampuan motorik kasar anak masih kurang berkembang sesuai harapan yang dapat dilihat dari aktivitas anak didik sehari-hari dalam melakukan aktivitas permainan dengan gerakan-gerakan yang tidak koordinasi secara beraturan, sehingga memerlukan strategi dan model permainan dalam mengembangkan kemampuan anak didik.

Kemampuan motorik merupakan kualitas hasil gerak individu dalam melakukan gerak, baik yang bukan gerak olahraga maupun gerak dalam olahraga atau kematangan penampilan keterampilan motorik. Proses motorik kasar adalah suatu kegiatan atau pelaksanaan yang menggunakan otot-otot besar pada diri anak yang menjadi dasar untuk mengikuti seluruh aktivitas gerak dasar lokomotor ataupun non lokomotor yang tersusun dari otot lurik sehingga dapat berfungsi untuk melakukan aktivitas gerak dasar yang terkoordinasi melalui otak, sehingga dapat merangsang dan melakukan kegiatan seperti; berjalan, melompat, menendang, berlari, memukul, melempar, mendorong, dan menarik sehingga dapat terkoordinasi melalui gerakan tubuh. Perbaikan untuk pelaksanaan, kegiatan, pandangan seperti ini haruslah diadakan guna untuk meningkatkan motorik kasar pada anak usia dini, khususnya pada permainan tradisional yaitu petak umpet.

Menurut Samsudin (2008) menyatakan bahwa Motorik dengan istilah "motor". Menurutnya, motor diartikan sebagai istilah yang menunjukkan pada hal, keadaan, dan kegiatan yang melibatkan otot-otot juga gerakannya, demikian pula kelenjar-kelenjar juga 
sekresinya (pengeluaran cairan/gatah). Secara singkat, motor dapat pula dipahami sebagai segala keadaan yang meningkatkan atau menghasilkan stimulasi/rangsangan terhadap kegiatan organ-organ fisik. Selanjutnya menurut Wiyani (2013) menyatakan bahwa Motorik kasar (gross motor skill), yaitu segala keterampilan anak dalam menggerakkan dan menyeimbangkan tubuhnya.Bisa juga diartikan sebagai gerakan-gerakan seorang anak yang masih sederhana, seperti melompat dan berlari

Upaya yang dilakukan dengan menerapkan permainan tradisional petak umpet dalam hal ini maka harapannya dengan menggunakan cara yang tepat pada permainan tradisional sehingga dapat memperbaiki dan meningkatkan dalam proses motorik kasar anak usia dini, dan dengan menggunakan permainan tradisional diharapkan dapat menjadikan guru dalam proses permainan tradisional lebih baik dan bisa meningkatkan motorik kasar pada anak usia dini. Permainan tradisional adalah satu bentuk yang berupa permainan anak-anak yang beredar secara lisan diantara anggota kolektif, serta banyak mempunyai variasi. Menurut Wahyuningsih, (2009) menyatakan bahwa Permainan tradisional atau yang biasa disebut dengan permainan rakyat yaitu permainan yang dilakukan masyarakat secara turun temurun dan merupakan hasil dari penggalian budaya lokal yang di dalamnya banyak terkandung nilai-nilai pendidikan dan nilai budaya, serta dapat menyenangkan hati yang memainkan secara berkelompok atau minimal dua orang. Permainan petak umpet merupakan permainan yang menyenangkan bagi anak yang dapat dimainkan dengan cara mencari teman-temannya yang bersembunyi. Selanjutnya menurut Achroni (2015) menyatakan bahwa petak umpet memang sangat populer di kalangan masyarakat dibandingkan dengan permainan tradisional lainnya, sebab permainan ini sangat mudah dimainkan dan kaya akan manfaat khususnya bagi anak usia dini. Anak usia dini yang berada dalam masa bermain tentu akan senang dengan kegiatan permainan petak umpet ini. Namun dengan kemajuan teknologi membuat banyak orangtua, guru mengesampingkan kebutuhan bermain anak dengan menggunakan teknolgi yang ada. Sehingga tujuan penelitian mengetahui tingkat kemampuan motorik kasar anak didik dengan melalui permainan tradisional petak umpet.

\section{METODE PENELITIAN}

Jenis penelitian ini adalah penelitian tindakan kelas (classroom action research) dengan pola guru sebagai peneliti, yaitu guru memiliki peran utama baik dalam perencanaan maupun dalam pelaksanaan PTK dengan tujuan untuk memecahkan masalah praktis yang dihadapi oleh guru itu sendiri dalam proses pembelajaran dimana jika guru melibatkan orang lain sifatnya hanya konsultatif untuk menjamin validitas tindakan yang dilakukannya menurut Sanjaya, Wina, (2009). Subyek dalam penelitian ini adalah seluruh anak usia 5-6 tahun kelompok B di TK Az-Zahra Tahun Ajaran 2020-2021 yang berjumlah 15 orang anak, terdiri dari 7 orang anak laki-laki dan 8 orang anak perempuan.

Desain penelitian ini menggunakan Penelitian Tindakan Kelas yang melibatkan partisipan, karena peneliti akan terlibat secara langsung dalam proses penelitian sejak awal sampai penelitian berakhir. Sejak perencanaan penelitian, peneliti senantiasa terlibat selanjutnya peneliti memantau, mencatat dan mengumpulkan data lalu menganalisa data serta berakhir dengan melaporkan hasil penelitiannya menurut Muslihuddin (2009). Teknik pengumpulan data yang digunakan dalam penelitian ini adalah observasi untuk melihat 
aktivitas tindakan guru dan dokumentasi terkait perkembangan penilaian keterampilan motorik kasar anak. Teknik Analisis data adalah suatu cara menganalisis data yang diperoleh selama peneliti mengadakan penelitian. Penelitian ini termasuk penelitian kuantitatif dan kualitatif. Data yang telah diperoleh secara kuantitatif kemudian dianalisis dengan analisis deskriptif persentase. Data kualitatif menerangkan aktivitas anak yang dapat diperoleh dari lembar observasi.

\section{HASIL DAN PEMBAHASAN}

Tahap pelaksanaan siklus I dimulai dengan tema "Lingkunganku" dan subtema "Rumahku" yang tahap pembelajarannya terdapat tiga tahap yaitu: Kegiatan Awal, Kegiatan inti dan Kegiatan Akhir. Kegiatan awal dilakukan dengan salam dan doa pada kegiatan awal yaitu anak datang dan diarahkan oleh guru untuk mencuci tangan lalu mengucapkan salam sebelum masuk ke dalam kelas, sebelum kegiatan pembelajaran di mulai anak didik membaca doa dan surah-surah pendek lalu bernyanyi dan setelah itu guru mengecek kehadiran anak didik. Anak didik di ajak bertanya jawab oleh guru mengenai pembelajaran kemarin apa dan pembelajaran hari ini masih dengan tema yang sama yaitu "Lingkunganku" dengan subtema "Rumahku" kemudian dilanjutkan dengan kegiatan permainan tradisional petak umpet. Kegiatan inti penelitian menjelaskan tentang aturan permainan tradisional petak umpet lalu melanjutkan dengan melakukan hompimpa agar ada yang berjaga setelah itu anak mulai melakukan permainan. Cara bermain anak sudah mulai bisa dikondisikan meskipun belum mencapai tahap sempurna setelah peneliti kembali menjelaskan ulang aturan permainan, setelah itu peneliti kembali mengevaluasi peserta didik. Kegiatan penutup, anak didik dipersilahkan untuk istirahat dan memakan dan meminum bekal yang dibawa dari rumah setelah anak beristirahat guru mengajak anak untuk melanjutkan pembelajaran setelah anak selesai mengerjakan pelajaran lalu anak diarahkan untuk berdoa dan mengucap salam sebelum pulang.

Tabel 1. Data Hasil Observasi Siklus I dalam Meningkatkan Kemampuan Motorik Kasar Anak Melalui Permainan Tradisional Petak Umpet

\begin{tabular}{|c|c|c|c|c|}
\hline Indikator & $\begin{array}{c}\text { Jumlah } \\
\text { Anak }\end{array}$ & Kriteria & $\begin{array}{c}\text { Presentase } \\
\text { Individu }\end{array}$ & $\begin{array}{c}\text { Presentase } \\
\text { Indikator \% }\end{array}$ \\
\hline \multirow{4}{*}{$\begin{array}{l}\text { Mampu Berjalan, berlari, } \\
\text { dan melompat pada saat } \\
\text { melakukan permainan } \\
\text { tradisional petak umpet }\end{array}$} & - & $\mathrm{BB}$ & - & \multirow{4}{*}{$86 \%$} \\
\hline & 1 & MB & $6,6 \%$ & \\
\hline & 6 & BSH & $25 \%$ & \\
\hline & 8 & BSB & $53,3 \%$ & \\
\hline \multirow{4}{*}{$\begin{array}{l}\text { Anak mampu melakukan } \\
\text { gerakan mata, tangan, kaki, } \\
\text { kepala secara terkoordinasi }\end{array}$} & - & $\mathrm{BB}$ & - & \\
\hline & 4 & MB & $13,3 \%$ & \multirow{3}{*}{$78,3 \%$} \\
\hline & 5 & $\mathrm{BSH}$ & $25 \%$ & \\
\hline & 6 & BSB & $44 \%$ & \\
\hline \multirow{4}{*}{$\begin{array}{l}\text { Mampu melakukan } \\
\text { permainan fisik permainan } \\
\text { tradisional petak umpet } \\
\text { dengan mengikuti aturan }\end{array}$} & 2 & $\mathrm{BB}$ & $3,3 \%$ & \multirow{4}{*}{$66 \%$} \\
\hline & 5 & MB & $16,6 \%$ & \\
\hline & 4 & $\mathrm{BSH}$ & $20 \%$ & \\
\hline & 4 & BSB & $26,6 \%$ & \\
\hline \multicolumn{4}{|l|}{ Rata-R } & $84 \%$ \\
\hline
\end{tabular}


Dari kesimpulan tabel diatas maka dapat dijabarkan indikator anak mampu Berjalan, berlari, dan melompat pada saat melakukan permainan tradisional petak umpet tidak ada anak pada kategori BB (Belum Berkembang), 1 anak mendapat kategori MB (Mulai Berkembang), 6 anak pada kategori BSH (Berkembang Sesuai Harapan), dan 8 anak pada kategori BSB (Berkembang Sangat Baik) sehingga presentase indikator tersebut yakni $86 \%$. Indikator anak mampu melakukan gerakan mata tangan, kaki, dan kepala secara terkoordinasi pada saat melakukan permainan tradisional petak umpet mendapatkan presentase yakni 4 anak mendapat MB, 5 anak mendapat BSH, dan 6 anak mendapat BSB sehingga keseluruhan presentase indikator tersebut yaitu 78,3\%. Indikator anak mampu melakukan permainan fisik permainan tradisional petak umpet dengan mengikuti aturan mendapatkan presentase 2 anak BB, 5 anak MB, 4 anak BSH, dan 4 anak BSB sehingga presentase indikator tersebut yakni $66 \%$. Rata-rata presentase pada siklus I pertemuan II yang didapatkan yaitu sebesar $84 \%$. Dari hasil penelitian tentang kegiatan yang terjadi selama proses kegiatan siklus I ini, menunjukkan hasil yang baik namun belum mencapai hasil yang maksimal mengingat masih ada beberapa anak didik yang belum memahami aturan permainan dengan baik dan benar.

Berdasarkan kegiatan refleksi hasil tes akhir hasil pengamatan dan catatan lapangan pada siklus I, maka dapat diperoleh beberapa hal pada indikator anak mampu berjalan, berlari,dan melompat saat melaksanakan permainan petak umpet, 1 anak yang masuk dalam kategori MB karena anak tersebut masih harus dibantu dan di bimbing oleh guru dan peneliti, 6 anak masuk dalam kategori BSH dikarenakan anak sudah mampu, berjalan, berlari dan melompat dengan baik dalam melakukan permainan tradisional petak umpet, 8 anak masuk dalam kategori BSB dikarenakan anak sudah mampu membantu dan mengajak temannya untuk berjalan, berlari dan melompat untuk melaksanakan kegiatan bersembunyi. Pada indikator anak mampu melakukan gerakan mata, tangan, kaki, kepala secara terkoordinasi saat melaksanakan permainan petak umpet tidak terdapat anak yang masuk kategori BB dikarenakan semua anak sudah mampu melakukan gerakan mata, tangan, kaki, kepala secara terkoordinasi, terdapat 4 anak yang masuk dalam kategori MB dikarenakan anak tersebut sudah mampu melakukan gerakan mata, tangan, kaki, dan kepala secara baik, 5 anak dalam kategori BSH dikarenakan anak sudah mampu melakukan gerakan mata, tangan, kaki dan kepala dengan baik dalam melakukan permainan tradisional petak umpet, 6 anak masuk dalam kategori BSB dikarenakan anak sudah mampu membantu dan mengajak temannya untuk melakukan gerakan terkoordinasi dengan baik dalam melaksanakan kegiatan bersembunyi. Pada indikator anak mampu melakukan permainan fisik permainan tradisional petak umpet dengan mengikuti aturan, terdapat 2 anak yang BB dikarenakan masih tidak dapat mengikuti aturan permainan fisik dengan baik dan benar dan masih belum bias menerima kekalahan, 5 anak masuk dalam kategori MB dikarenakan anak tersebut masih bersembunyi di tempat yang sama, 4 anak BSH dikarenakan sudah mampu mengikuti aturan permainan fisik dengan baik dan benar yaitu dengan mencari empat persembunyian sendiri tanpa berkumpul dengan teman lainnya, 4 anak masuk dalam kategori BSB dikarenakan anak tersebut telah mampu mengikuti aturan permainan fisik dengan baik dan benar serta mampu membantu teman lainnya mencari tempat persembunyian.

Tahap pelaksanaan siklus II dilaksanakan dengan tema "Lingkunganku" dan subtema 
"Rumahku" yang tahap pembelajarannya terdapat tiga tahap yaitu: Kegiatan Awal, Kegiatan inti dan kegiatan Akhir. Kegiatan awal dilakukan dengan salam dan doa pada kegiatan awal yaitu anak datang dan diarahkan oleh guru untuk mencuci tangan lalu mengucapkan salam sebelum masuk ke dalam kelas, sebelum kegiatan pembelajaran di mulai anak didik membaca doa dan surah-surah pendek lalu bernyanyi dan setelah itu guru mengecek kehadiran anak didik. Anak didik di ajak bertanya jawab oleh guru mengenai pembelajaran kemarin apa dan pembelajaran hari ini masih dengan tema yang sama yaitu "Lingkunganku" dengan subtema "Rumahku" kemudian dilanjutkan dengan kegiatan permainan tradisional petak umpet. Kegiatan inti dilakukan dengan guru menjelaskan kembali tentang aturan permainan tradisional petak umpet lalu melanjutkan dengan melakukan hompimpa agar ada yang berjaga setelah itu anak mulai melakukan permainan. Cara bermain anak sudah mulai bisa dikondisikan setelah peneliti kembali menjelaskan ulang aturan permainan, setelah itu peneliti kembali mengevaluasi peserta didik. Pada pertemuan terakhir ini anak-anak sudah mulai terbiasa dengan permainan tradisional petak umpet dan cara bermain anak-anak sudah meningkat dari hari pertama hingga akhir penelitian. Kegiatan penutup, anak didik dipersilahkan untuk istirahat dan memakan dan meminum bekal yang dibawa dari rumah setelah anak beristirahat guru mengajak anak untuk melanjutkan pembelajaran setelah anak selesai mengerjakan pelajaran lalu anak diarahkan untuk berdoa dan mengucap salam sebelum pulang.

Tabel 2. Data Hasil Observasi Siklus II tentang tingkat Kemampuan Motorik Kasar Anak Melalui Permainan Tradisional Petak Umpet

\begin{tabular}{|c|c|c|c|c|}
\hline Indikator & $\begin{array}{c}\text { Jumlah } \\
\text { Anak }\end{array}$ & Kriteria & $\begin{array}{l}\text { Presentase } \\
\text { Individu \% }\end{array}$ & $\begin{array}{l}\text { Presentase } \\
\text { Indikator\% }\end{array}$ \\
\hline \multirow{4}{*}{$\begin{array}{l}\text { Mampu Berjalan, berlari, } \\
\text { dan melompat pada saat } \\
\text { melakukan permainan } \\
\text { tradisional petak umpet }\end{array}$} & - & $\mathrm{BB}$ & - & \multirow{4}{*}{$91,6 \%$} \\
\hline & - & MB & - & \\
\hline & 5 & $\mathrm{BSH}$ & $25 \%$ & \\
\hline & 10 & BSB & $66,6 \%$ & \\
\hline \multirow{4}{*}{$\begin{array}{l}\text { Anak mampu melakukan } \\
\text { gerakan mata, tangan, kaki, } \\
\text { kepala secara terkoordinasi }\end{array}$} & - & $\mathrm{BB}$ & - & \multirow{4}{*}{$90 \%$} \\
\hline & - & MB & - & \\
\hline & 6 & BSH & $30 \%$ & \\
\hline & 9 & BSB & $60 \%$ & \\
\hline \multirow{4}{*}{$\begin{array}{c}\text { Mampu melakukan } \\
\text { permainan fisik permainan } \\
\text { tradisional petak umpet } \\
\text { dengan mengikuti aturan }\end{array}$} & - & $\mathrm{BB}$ & - & \multirow{4}{*}{$80 \%$} \\
\hline & - & MB & - & \\
\hline & 9 & $\mathrm{BSH}$ & $45 \%$ & \\
\hline & 6 & BSB & $40 \%$ & \\
\hline \multicolumn{4}{|c|}{ Rata-Rata Presentase\% } & $97 \%$ \\
\hline
\end{tabular}

Dari kesimpulan tabel diatas maka dijabarkan indikator anak mampu Berjalan, berlari, dan melompat pada saat melakukan permainan tradisional petak umpet mendapatkan presentase 5 anak BSH, dan 10 anak BSB sehingga presentase indicator tersebut yakni telah mencapai 91,6\%. Indikator anak mampu melakukan gerakan mata tangan, kaki, dan kepala secara terkoordinasi pada saat melakukan permainan tradisional petak umpet mendapatkan presentase yakni, 6 anak mendapat BSH, dan 9 anak mendapat BSB sehingga keseluruhan presentase indikator tersebut yaitu $90 \%$. Indikator anak mampu melakukan permainan fisik permainan tradisional petak umpet dengan mengikuti aturan mendapatkan presentase 9 
anak BSH dan 6 anak BSB sehingga presentase indikator tersebut yakni telah mencapai $80 \%$. Rata-rata presentase pada siklus II yang didapatkan yaitu sebesar $97 \%$. Dari hasil penelitian tentang kegiatan yang terjadi selama proses kegiatan siklus II ini, menunjukkan hasil yang maksimal dan sangat jelas terlihat perbedaannya hasil yang dicapai dengan pembelajaran kegiatan sebelumnya. Dimana pada siklus II mengalami peningkatan yang baik jika dibandingkan dengan pembelajaran pada siklus sebelumnya. Hal ini didasarkan pada refleksi yang ditemukan yaitu cara penjelasan oleh peneliti kepada para anak didik yang terus berulang-ulang sehingga membuat anak didik semakin paham dan semangat dalam melakukan permainan tradisional petak umpet.

Berdasarkan kegiatan refleksi hasil tes akhir hasil pengamatan dan catatan lapangan pada siklus II maka dapat diperoleh beberapa hal yaitu pada indikator anak mampu berjalan, berlari,dan melompat saat melaksanakan permainan petak umpet, 5 anak masuk dalam kategori BSH (Berkembang Sesuai Harapan) dikarenakan anak sudah mampu, berjalan, berlari dan melompat dengan baik dalam melakukan permainan tradisional petak umpet, 10 anak masuk dalam kategori BSB (Berkembang Sangat Baik) dikarenakan anak sudah mampu membantu dan mengajak temannya untuk berjalan, berlari dan melompat untuk melaksanakan kegiatan bersembunyi. Pada indikator anak mampu melakukan gerakan mata, tangan, kaki, kepala secara terkoordinasi saat melaksanakan permainan petak umpet tidak terdapat anak yang masuk kategori BB (Belum Berkembang) dikarenakan semua anak sudah mampu melakukan gerakan mata, tangan, kaki, kepala secara terkoordinasi, tidak terdapat lagi anak yang masuk dalam kategori MB (Mulai Berkembang) dikarenakan anak sudah mampu melakukan gerakan mata, tangan, kaki, dan kepala secara baik, 6 anak dalam kategori BSH (Berkembang Sesuai Harapan) dikarenakan anak sudah mampu melakukan gerakan mata, tangan, kaki dan kepala dengan baik dalam melakukan permainan tradisional petak umpet, 9 anak masuk dalam kategori BSB (Berkembang Sangat Baik) dikarenakan anak sudah mampu membantu dan mengajak temannya untuk melakukan gerakan terkoordinasi dengan baik dalam melaksanakan kegiatan bersembunyi.

Pada indikator anak mampu melakukan permainan fisik permainan tradisional petak umpet dengan mengikuti aturan, 9 anak BSH (Berkembang Sesuai Harapan) dikarenakan sudah mampu mengikuti aturan permainan fisik dengan baik dan benar yaitu dengan mencari empat persembunyian sendiri tanpa berkumpul dengan teman lainnya, 6 anak masuk dalam kategori BSB ( Berkembang Sangat Baik) dikarenakan anak tersebut telah mampu mengikuti aturan permainan fisik dengan baik dan benar serta mampu membantu teman lainnya mencari tempat persembunyian. Penerapan tradisional petak umpet merupakan kegiatan yang efektif dalam meningkatkan keterampilan motorik kasar dimana sejalan dengan Dewi, N. C. (2013) dalam melaksanakan layanan pengembangan motoric kasar guru hendaknya memfasilitasi anak dengan menggunakan metode-metode pembelajaran berbasis permainan tradisional khususnya petak umpet yang variatif agar anak mandiri, dapat menaati aturan permainan, dan motorik kasarnya berkembang dengan optimal. 


\section{SIMPULAN}

Hasil penelitian setelah dilakukan tindakan selama dua siklus adalah ada siklus I dengan indikator anak mampu berjalan, berlari, dan melompat pada saat melakukan permainan tradisional petak umpet didapatkan hasil presentase yaitu $79 \%$, pada indikator anak mampu melakukan gerakan mata, tangan, kaki, dan kepala dalam melakukan permainan tradisional petak umpet didapatkan hasil presentase yaitu $70 \%$ sedangkan pada indikator anak mampu melakukan permainan fisik permainan tradisional petak umpet dengan mengikuti aturan didapatkan hasil presentase yaitu hanya mencapai $43 \%$ dan hasil rata-rata presentase dari siklus I yaitu hanya mencapai $64 \%$ maka hal tersebut belum mecapai indikator keberhasilan yaitu sebesar $80 \%$. Pada siklus II dengan indikator anak mampu berjalan, berlari, dan melompat pada saat melakukan permainan tradisional petak umpet didapatkan hasil presentase yaitu $82 \%$, pada indikator anak mampu melakukan gerakan mata, tangan, kaki, dan kepala dalam melakukan permainan tradisional petak umpet didapatkan hasil presentase yaitu $83 \%$ sedangkan pada indikator anak mampu melakukan permainan fisik permainan tradisional petak umpet dengan mengikuti aturan didapatkan hasil presentase yaitu hanya mencapai $65 \%$ dan hasil rata-rata presentase dari siklus II yaitu mencapai $82 \%$ maka hal tersebut telah mencapai indikator keberhasilan.

\section{DAFTAR PUSTAKA}

Acroni Keen. 2012. Mengoptimalkan tumbuh kembang anak melalui permainan tradisional. Jakarta: Pranada Media Group

Anita Yus. 2011. Penilaian Perkembangan Belajar Anak Taman Kanak-Kanak. Jakarta: Kencan Prenada Media Group

Askalin. 2013. 100 Permainan dan Perlombaan rakyat, Yogyakarta: Andi Offset

Bambang, Sujiono. 2008. Metode Pengembangan Fisik, Jakarta: Universitas Terbuka

Daulay Zainal, 2011. Pengetahuan Tradisional.Jakarta: rajagrafindo persada

Dewi, N. C. (2013). Penerapan permainan tradisional petak umpet variatif untuk meningkatkan perkembangan motorik kasar anak TK A PAUD Laboratorium UM Kota Blitar. Penerapan permainan tradisional petak umpet variatif untuk meningkatkan perkembangan motorik kasar anak TK A PAUD Laboratorium UM Kota Blitar/Novia Candra Dewi.

Euis Kurniati. 2016. Permainan Tradisional dan Perannya Dalam Mengembangkan Keterampilan Sosial Anak. Jakarta: Prenada Media Group

Elizabeth B. Hurlock, 1978. Perkembangan Anak. Jakarta: Penerbit Erlangga

Endang Rini Sukamti, (2007), Diklat Pembelajaran Motorik. Yogyakarta: FIK UNY

Gallahue, David L, Oznum John C, \& Jacqueline D. Goodway. 2012. Understand Motor Development: infant, children Adolencent, Adults, Seventh Edition. New york: McGraw-Hill

Hartati Sofia. 2005. Perkembangan Belajar Pada Anak Usia Dini. Jakarta: Departemen Pendidikan Nasional

Herdina Indrijati. 2017. Psikologi Perkembangan \& Pendidikan Anak Usia Dini. Jakarta: Kencan 
16| TEMATIK, Juni 2021, Volume 7, Nomor 1, Halaman 8-16

Iriyanto. 2012. Hebat Gurunya Dahsyat Muridnya. Erlangga: Erlangga Group

Latif Mukhtar, dkk, 2013.Orientasi Pendidikan Anak Usia Dini.Jakarta: Kencana Media Group

Mansur. 2005. Pendidikan Anak Usia Dini Dalam Islam. Yogyakarta: Pustaka Pelajar

Mini Romi, dkk, 2010. Panduan Mengenal Dan Mengasah Kecerdasan Majemuk Anak.Jakarta: Indocam Prima

MS Sumantri, 2005. Pengembangan Keterampilan Motorik Kasar Anak Usia Dini. Jakarta: Dinas Pendidikan

Musfiroh, Tadkiroatun, 2005. Bermain Sambil Belajar dan Mengasah Kecerdasan.Jakarta. Depdiknas.

Muslihuddin, 2009.Kiat Sukses Melakukan Tindakan Kelas (Panduan Praktis bagi Guru dan Tenaga Kependidikan, Bandung: Rizqi Press

Mulyani Novi, 2016. Super Asyik Permainan Tradisional Anak Indonesia. Yogyakarta: Diva Press

Murtafi'atun, 2018. Kumpulan Permainan Tradisional Nusantara. Yogyakarta: Ckilk Media

Ngalim Purwanto, (2010) Prinsip-Prinsip dan Teknik Evaluasi Pengajaran. Bandung: Remaja Rosdakarya

Mukhtar Latif, dkk. 2013. Orientasi Pendidikan Anak Usia Dini. Jakarta: Kencana Media Group

Sanjaya, Wina. 2009. Strategi Pembelajaran Berorientasi Standar Proses Pendidikan. Prenada: Jakarta

Soematri Patmonodewo, 2003. Pendidikan Anak Pra Sekolah.Jakarta: Rineka Cipta

Sukintaka, 2001. Teori Pendidikan Jasmani. Solo: Esa Grafika

Wahyudi dan Dwi R, 2005. Program Pendidikan Anak Usia Dini di Prasekolah (Cet I; Jakarta: Grasindo

Wahyuningsih Sri, 2009. Permainan tradsional untuk usia 4-5 tahun. Bandung: Sandiarta Sukses 